\title{
Provision and Usage of Computer and Internet Facilities at the College Of Education of the University Of Rwanda
}

\author{
${ }^{1}$ Mr. Irénée Ndayambaje, ${ }^{2}$ Prof. John Aluko Orodho $(\mathrm{PhD})$ \\ ${ }^{I}$ Department of Educational Management, Policy, and Curriculum Studies, School of Education at Kenyatta \\ University. He has been the first Coordinator of Tele-Education/learning at former Kigali Institute of Education \\ now changed into the College of Education of the University of Rwanda (UR). \\ ${ }^{2}$ Associate Professor in the Department of Department of Educational Management, Policy, and Curriculum \\ Studies, School of Education, Kenyatta University, Kenya.
}

\begin{abstract}
The gist of this paper is to assess the provision and usage of computer and internet facilities at the college of education of the University of Rwanda. The study had three fold objectives: i) determine the level of provision of computer and internet facilities, ii) determine the level of satisfaction in the usage of computer and internet facilities by students and lecturers, iii) highlight the challenges in the use of computer and internet and devise remedial measures. The study was based on a resource based approach theory. The study employed a descriptive survey research design. Purposive sampling technique was employed to select 134 respondents constituting 95 students and 33 academic members of staff. Both quantitative and qualitative approaches were used to collect and analyze data. The findings revealed on one hand that the investigated Information and Communication Technology (ICT) facilities -computer and access to internet connectivity- were not yet satisfactory and even not deeply integrated into teaching and learning. The major challenges observed are notably improper maintenance and poor service delivery reported against ICT technical staff, lack of advanced ICT literacy and zeal to change the old practices for some lecturers and the large use of the internet connectivity for non-academic purposes. It is recommended that the Government of Rwanda, through the relevant line ministries, should put in place and strictly enforce an ICT policy that removes all constraints to access to the technology literacy and application in order to enable lecturers, students and wider Rwandese community cope with the currently highly digitalized world .(253 words).
\end{abstract}

Key words: Information and Communication Technologies (ICTs), Computers, provision and usage, ICT policy, digital world, Rwanda.

\section{Background}

\section{Introduction}

The Rwanda education system experienced transformation depending on the political context of the moment( Mukama,2012).Hayman (2005) explains that before the genocide of 1994, the system was discriminatory, while the quality of education was poor, vocational and technical education seriously weak( Mukama,2012).As reflected on the study on Education sector in Rwanda (MINEDUC,1998), after 1994, education became a tool for unity and reconciliation( Mukama,2012).The major innovation in the education sector is that the Rwanda Vision 2020 strongly recommends that the education sector should focus on promoting science and Technology, teacher education and human resource for economic and social development of the country( Government of Rwanda,2001).The same vision 2020 considers the implementation of Information and Communication Technology (ICT) as one of the top priorities of the county(MINICOFIN,2001). A related integrated -led socioeconomic development policy and plan envisaged that at least 5 computers and 10 computers were to be deployed in each primary and secondary school, respectively (Mukama, 2012). However, a study by Mukama and Anderson (2008) revealed that this plan was too ambitious given that most schools even those located in urban areas did not have electricity let alone telephone lines.

The study by Mukama et.al (2008) further revealed that urban primary schools seemed to be better equipped in terms of human and material resources and infrastructure compared $t$ other public schools especially from rural areas. This became much more visible when the Government of Rwanda had to implement the One Laptop per Child (OLPC)pilot project in primary schools( Mukama,2012).Most schools selected were located in urban areas nt necessarily because they were there, but because they presented minimum requirements in terms of infrastructure (i.e electricity) to implement the projects. Thus in 2007 and 2008, the OLPC Corporation donated 10,000 computers to Rwanda in November 2009 and most of these were deployed in urban schools including Rwamangana located in Eastern Province, Kagugu and Nonko situated in Kigali City (NIMEDUC, 2009). Additionally, the Government of Rwanda for their deployment all over the country ordered 100,000 OLPC. This 
confirms the extent to which the Government of Rwanda is committed to ensuring a computer literate citizenry.

No wonder, in today's world, almost all human activities are facilitated by the potential of computers and Internet. It is in this regards that education as key for social-economic development has also fast embraced the benefits that holds these Information and Communication Technologies (ICTs) tools. Historically, Pelgrum and Law (2003) demonstrated that ICTs have been fast growing and coming up with more solutions. They have shown that computers which came to be know in education by early 1980s moved fast into Information Technology (IT) before the end of the same decade due to the new added value in terms of the ability to store and retrieve information. It is in the last 1990s that again IT moved into ICT as a consequence of the availability of more interactivity and reach brought by electronic mail (email) and the World Wide Web (WWW).It is a against this background that this study made an attempt to assess the assess the provision and usage of computer and internet facilities at the college of education of the University of Rwanda

Literature Review

In line with the above, Auerswald and Magambo (2006) have clearly stated that with the worldwide fast increase of ICTs, every one shall be compelled to acquire and learn about these. At the institutional level, the imperative is more sensitive. Educational institutional institutions in particular have to equip themselves with all required ICT if they do not want to stay behind in this fast moving world in terms of knowledge, skills and tools.

On behalf of Sahin, Balta and Ercan (2010), the benefits of Internet in educational context are evident. These authors highlight for instance the increase of collaboration and the potential to access many educational resources from anywhere and anytime. In university teaching and learning scenarios, Selwyn (2006) recalls that 'the potential of computer technologies to revolutionize university teaching and learning has long been celebrated by education technologists'. That being, provision and usage of ICTs (computers and Internet as per this study) are no longer a matter of choice but rather a must.

In Africa, the Survey of ICT and Education in Africa conducted by Farrell and Shafika (2007) has drawn a number of recommendations among which Higher Education in Africa were called to give more attention to ICT infrastructures.

A study by Amenyedzi, Lartey and Dzomeku (2011) conducted in Ghana has revealed that although there has been a limited use of computers by teachers in teaching, respondents acknowledged the undeniable change that computers have brought in the way students learn. In Uganda, a study carried out by Kaahwa (2013) proved that university students, teachers and head teachers needed new computers. In parallel to this, continuous training in ICT itself and how to use it in various subjects was highlighted as a key towards success.

For the case of Rwanda, the Government is committed to transform the country into a knowledge based society whereby ICT is considered as key pillar. In this respect, the President of Rwanda Paul Kagame is reported by Nsengiyumva \& Stork (2005) to have argued that 'productive capacities in modern economies are not based merely on capital, land and labour. They are also dependent on scientific knowledge and sustained technological advances". These words translate a clear dedication of this nation to boost considerably the economy via the application of science and technology.

Following the above political will and orientation, different initiatives and policies related to the provision and usage of ICT facilities in Rwandan education sector were set out right from primary to higher education. To illustrate this, at the Primary school level, one laptop per child (OLPC) project was piloted in Rwamangana District, Eastern Province whereby all 110 primary year five (P5) pupils received the laptops (Murenzi, 2008). Recently, "the distribution of OLPCs reached 115,816 units, covering 227 schools and digital content were also deployed" (Ministry of Youth and ICT, 2012).

At secondary school level, the Ministry of Education (MINEDUC) established 12 secondary schools as centers of excellence in Science and ICT. This was supplemented by National school-net project that provided 2700 computers for 270 secondary schools (Crest, 2007). At higher learning, all public institutions have also been provided with ICT facilities. They were indeed recalled the mandate as per Education Sector Plan 2006-2010 to improve, modernize and promote the development of science and technology teaching in line with the development goals of Rwanda (MINEDUC, 2007 \& MINEDUC, 2010).

Educational institutions both in developed and developing countries are striving to equip themselves with computer and Internet facilities. The motivation behind is based on the belief that these institutions will benefit first from the use of these new technologies but also they feel concerned with the need to respond to the real fact that students have to be exposed to these gadgets right from the school environment (Osorio \& Linden, 2009). 
In a survey of more than 2,000 teachers and school principals across the United States, teachers confirmed at $92 \%$ and $88 \%$ that technology enabled them to be more effective and creative respectively. Also was agreed by both teachers and administrators investigated, that technology had really strengthened teaching and learning on behalf of students because they were seen to be more enthusiastic to ask questions and participate in the lessons (Haddad \& Jurich, 2002).

At higher education, computers and Internet are not only educational tools, but also a condition for accreditation and responsiveness to the societal change and growth. That is the reason why Akande (2011) urges once more that education has to generate graduates who best fit the 21 st century world today. Still emphasizing the power of Internet in education, Akande (2011) quotes the study carried out by Ramirex (2003) on the impact of the Internet on the reading practices of College students in National University of Mexico. In this study, it was found out that a momentous portion of investigated students reported to use most of the times Internet to handle school - related activities, the prime reason being that it was effortless and speedy.

In brief, computers and Internet make learning more fun, constitute viable and updated sources of information but even extend the knowledge application. Hence, they should be advocated and enforced as integral part of education systems rather than just supplement (Hollowell, 2012 cited by Kaahwa, 2013).

In terms of usage and challenges of computers and internet in education, Capshaw (2007) has shown that computers and Internet give lecturers and students the opportunity to use multimedia, simulation, information databases, virtual laboratories, and transmission of assignments electronically. Moreover, these technologies are known to have the potential to radically alter positively the higher education system as they make learners more active, modernize the modes of instruction delivery, empower lecturers, enhance communication among students and lectures, increases access to depository of knowledge and alleviate the barriers of time and distance to provide whatever needed educational services (Duderstadt, Atkins \& Houweling, 2002).

Despite the above, Hermes (2012) has realized that compared to other sectors, education is seen to be still lagging behind in technology. In view of this, Haddad and Jurich (2002) attempted to explain this phenomenon from the research standpoint. They reported that from their findings some teachers complained that technology was taking off their usual powers to the knowledge and the classroom. Also was highlighted that the use of computers and technology was incurring more expensive to schools but also conflicting with other priorities.

Roekel (2008) also found out that in spite of the largely advancement of ICTs, schools have not yet embraced maximally the use of computers and ICTs. In fact, this author went far to mention that even the rhythm of implementation is slow not only due to competitive priorities but also as a consequence of lack of adequate information, funds and the know- how. Indeed, such delays and inactivity are associated to teachers' attitudes, motivation and perception (Sang, Valcke, Braak, Tondeur \& Zhu, 2010).

The above literature demonstrates clearly that although the advantage towards the use of computers and Internet seem to be evident, their full usage and enforcement as educational tool is still hard due to varied factors including human, financial, administrative and institutional factors (Friedrich \& Hron, 2011).

\section{Statement of the problem}

Investment in ICT purchase, installation and maintenance occupy $40 \%$ of public higher education budget (Ssempebwa, Canene \& Mugabe, 2007) and still teaching and learner are not totally revolutionized by ICTs. This is a challenging situation in view of the Government of Rwanda's target to transform the economy through the application of ICTs in all sectors; higher education playing the key role.

\section{Purpose and objectives}

This study aimed to investigate into the existence and usage of computer and Internet facilities at former Kigali Institute of Education (KIE). Hence, researchers were guided by the following three research objectives: i)Determine the level of provision of computer and Internet facilities;

ii) Show the level of satisfaction and usage of computer and Internet facilities by students and lecturers; iii)Highlight the challenges in usage of computer and Internet facilities and propose remedial solutions.

\section{Theoretical framework}

This study was guided by 'the resource-based theory' also known as resource-based view (RBV) or resourcebased approach. This theory attempts to understand and demonstrate why organizations or firms do differ from 
one another and even how they mobilize their resources to achieve the fixed goals. According to Conner (1991), Barney (1991) and Sciarelli (2008), the resource-based theory provides an understanding into the way firms and organizations conceive of and implement strategies that improve their efficiency and effectiveness key conditions towards the attainment of sustainable competitive advantages.

In this theory, the key concept is 'resources' which include skills, knowledge, expertise, finance, materials, human and technological among others which all together are employed to enlarge, produce, and convey goods and services to customers. According to Kostopoulos, Spanos and Prastacos (n.d), the pioneer of this theory is Penrose who in 1959 was interested to explain the uniqueness of organizations based on their heterogeneity character. It is late in the 1980's that this theory was also borrowed to be used in the field of strategic management. In fact, the organizational capacity is measured in terms of its ability to convey strategically its resources. Strategies here refer to 'the march that an organization makes between its internal resources and skills...and the opportunities and risks created by its external environment" (Grant, 2001), This statement leads to notice that organizations operate in a competitive environment that requires the use of a number of interrelated strategies including service delivery, imitation, skills and technologies.

Summarily, the resource-based theory focuses on how inputs (resources) should constitute a foundation for an organization/firm to deliver and outperform competitors. A resource-based view of the firm accepts that attributes related to past experiences, organizational culture and competences are critical for the success of the firm (Hamel and Prahalad, 1996). It enables therefore managers to understand how those assets are important to improve business performance.

\section{Research Methodology}

A descriptive research design was used in this study. The population of this study comprised 1,163 Level 3 day programme students and 168 academic staff of former KIE. In total, 134 people were investigated and hence formed the sample to the present study. Both men and women put together, 95 participants were students while were 33 academic/teaching staff all faculties represented. In fact, the data collection stage arrived by the time students and lecturers were busy with end of semester examinations and hence sampling targeted those who were available and were willingly ready to participate. However, a purposive sampling technique was also used to include well informed people. These are two deans and fours heads of departments.

Three types of instruments were used to collect necessary data. These are questionnaires addressed to students and academic staff, the interview guide to heads of department and deans and the field inventory used by the researcher himself while exploring the existing computer and Internet facilities. Freedom of expressed and confidentiality of provided answers were assured.

In order to test the validity of the designed instruments, the researchers subjected them to colleagues and more experimented people in research for their suggestions. Necessary corrections were done before using the instruments for data collection. To test the reliability, designed questionnaires were subjected to a pre-testing with 30 people. The results were analyzed using the split-half reliability method. These questionnaires were revealed to be reliable because the reliability coefficient for the test was 0.75 for the students' questionnaire while it was 0.74 for the academic staff questionnaire. Both qualitative and quantitative approaches to analyze data were used and the findings were discussed in light of the theoretical framework and the developed literature review.

\section{Findings And Discussion}

Level of provision and access to computer and Internet ICT facilities

The figure below shows that there have been considerable efforts in terms of the provision of computers since 1999 up to 2009.

Figure 1: Growth in computer assets from 1999 to 2009

In fact, in ten years time, the number of computers moved from five to reached 1,310. However, from the above mentioned number of computers, only 320 were reported to be used for teaching and learning purposes for a population of 5,573 students which gives a computer student ratio of 1/17.4. Such a ratio is still a big challenge and is one of the sources of dissatisfaction about the access to ICT facilities expressed by investigated students. Hence, there is no how ICT should really penetrate in teaching-learning scenario with such a discrepancy. This is well supported by Venezky and Cassandra (2002) who have demonstrated that infrastructure and equipments constitute basic requirements for successful implementation of ICT. 
Moreover, the problem of access to computer and Internet facilities was again reported by students to be increased by the fact that only $11 \%$ have own laptops and a limited time is given to any student to access freely the existing computer labs because most of the times; the four Internet connected computer labs are used for computer teaching or practical works organized and supervised by lecturers; a managerial condition threatening the access to ICT facilities also underlined by Mukama and Anderson (2007). The investigated students have also reported that not all computers in these labs are connected to Internet and sometimes the connectivity is not assured or speedy.

On the academic staff's side, $100 \%$ asserted that they have access to computers (own laptop and/or institutional desktops). However, only $30 \%$ of them have agreed that they have continuous access to Internet which means that $70 \%$ don't or rarely access Internet. These views show that really lecturers do not maximally exploit the benefits that Internet holds for education which might be impeding on their academic life and related duties. The limited use may be due to limited skills but even to lack of proper support because as confirmed by Maldonado (2001) 'teachers use computers more effectively in schools offering high levels of teachers' development and avails coordinators to assist them with ongoing problems'.

Usage of computer and Internet facilities and challenges faced

Computer and Internet as educational facilities are being used differently by investigated lecturers and students. In a priority order, the table below presents summarily the responses of lecturers and students about what takes much of their time once working with these.

Table

Lecturers' statements \% Students' statements \% Preparing examinations 100 Mailing friends and relatives outside and inside the campus 76.8 Preparing lecture notes 90.9 Games and fashions 60 Mailing 81.8 Supplementing lecture notes and searching materials for assignments 47.4 Supplementing materials available for teaching 72.7 Downloading stars' video music 44.2 Recording marks 72.7 Watching film 40 Lecturing 45.5 Accessing academic notices and regulations 24.2 Reading and listening to worldwide news 36.4 Downloading software 21.1 Preparing take home assignments 33.3 Interacting with lecturers for academic purposes 4.2 Providing public lectures and conferences 15.2 Monitoring own results and progress $0 \quad$ Tele-collaboration/working with world-class researchers on academic projects 12.1 Accessing syllabuses and modules 0

From the table above, only $45.5 \%$ of the investigated lecturers have agreed that they use computers as they teach. In line with that, $39.39 \%$ disagreed while $48.48 \%$ strongly disagreed with the statement that the teaching content in this institution has been carefully developed to integrate several teaching approaches and ICT usages. The analysis leads to conclude that teaching in much using the traditional chalk and talk.

The same reality came out from the data collected from the investigated students who ranked verbal lecturing and chalkboard use as the most teaching strategies used by lecturers. Hence, a total shift to ICT modes is yet to be achieved and requires that lecturers be trained and educated on educational benefits of this technology as proposed by Pedro (2005).

In fact, traditional approaches might be supported by the fact an advanced computer literacy is not yet achieved by all lectures especially for those aged as asserted by lecturers who participated in the study. Hence, an advanced implementation of ICT would be expected if the issue of computer skills was also adequately addressed. The reason is that 'ICT use, just like anything else in schools, depends on teacher skills' (Cornoy, 2004).

Still on the lecturers' side, the low integration of ICT is not only impeding on the quality of teaching and learning but also is impacting much on the research side. The support to this argument is that only $15.2 \%$ of the lecturers have asserted to have provided public lectures and only $12.1 \%$ have been telecollaborating with other researchers on academic projects. Hence, there is little hope that these academicians bring about change in educational, social and economical dimensions if they do not get in today's dynamic digital world (Osorio \& Linden, 2009).

On behalf of students, the findings have shown that there is a very little usage of computer and Internet facilities towards academic purposes. Rather, other motivational elements have taken the drive which lead researchers to a deep analysis and interpretation of the scenario. In fact, asked about what takes priority and much of their time once in the labs, $76.8 \%$ of students reported to open up emails, write/reply and chart. The second ranked priority 
was searching about updates in games and fashion $(60 \%)$ while supplementing the lessons $(47.4 \%)$ and interacting with lecturers occupied low/negligible percentages (4.2\%).

The explanation to such attitude can be attributed to the young age of the investigated university students which average was 20.7. The scientific support of this inference is drawn from the studies of Bashir, Mahmood and Shafique (2008) and the one of Sahin, Balta and Ercan (2010) who have found out that in case of adolescents as it is the case of some young university students, entertainment takes much of the time and hence the effects of the Internet in education seem to be related limited.

This study has also disclosed the existence of a limited interest in the use of the institution website by students. Truly, none of the investigated students reported that s/he uses it neither to check his academic scores or accessing syllabuses and modules. This leads to conclude that the institutional units are not doing much to exploit this important managerial and communication tool. On this point Balasubramanian (2009) argues that effective embracement of ICTs in education also implies modernizing the practices being online access to course outlines and materials, online assignment submissions, online examinations and online discussion forums with students and instructors, among others.

Participants in the study point out as well that the limited usage of computer and Internet facilities is humped by lack of adequate support and services from ICT staff. To illustrate this, some of the investigated lecturers have reported to have taken their office desktop computers for repair but these never brought back which leads one to understand why about 200 defected and unrepaired computers are lying in stores and ICT workshops.

One the issue of ICT poor service, one of the lecturers has communicated the followings:

There has been a technical problem with cabling, which I detected and reported. A staff from ICT department was tasked to fix the problem in one day time, which he never did. I went several times to see him, his colleagues and even his line manager but now it is about 6 months none has cared about and yet there are there being monthly paid.

This statement joins the findings of Venezky and Cassandra (2002) who underlined clearly that even if teachers may be familiar with ICT, additional technical support is needed.

Students complained too about insufficient time of access, irregularity and poor services of IT support staff. As support to their statements, two of the investigated students affirmed to have brought their laptops to get keys for wireless connection and failed to get ICT staffs who were supposed to assist them. These findings calls for a managerial action because, ICT adoption requires apt support (Sang, Valcke, Braak, Tondeur \& Zhu, 2010). Indeed, students willing ready to use ICTs should be served and much encourage since as of fact 'those who used a computer effectively should have outperformed those who did not' (Zhou et al., 2012).

\section{Conclusion And Recommendations}

First, while there has a been a continuous increase in computer facilities, the findings in this study have shown that the level of provision has not yet been satisfactory in view of the numbers of end-users. Indeed, it was found out that despite the efforts made, teaching and learning have not yet fully embraced the use of ICTs.

Second, the analysis of the data collected enabled to discover that the limited use of computer and Internet is associated with limited skills, a high computer-student ratio, and dominant use of Internet for non academic oriented activities by students and poor support and service delivery of ICT staff.

Third, researcher participants foresee a hope to attain a deeper ICT integration level if there is a strong commitment and policy enforcement right from top line managers to come up with new and bold solutions that hamper technology use and computer literacy; a solution proposed also by Ziphorah (2011). In fact, in this institution the pasture seems already prepared because as per data in the table presented $90.9 \%$ of the lecturers provide computer typed handouts which infers that handwritten materials were highly abandoned. On the other hand also none of the students has reported that s/he cannot operate a computer at a satisfactory level. Such 'computer motivation' attitudes as coined by Sang, Valcke, Braak, Tondeur \& Zhu (2010) constitutes actually a better starting point to build upon.

Finally, for the institution, researchers recommend first the increase of access to computer and Internet facilities, a solution proposed by Roekel (2008). In addition, there is a clear imperative to put in place an ICT policy that would push both lecturers and students to cope with the modern world that calls for more interaction and 
collaboration by extending the learning environment beyond the physical classroom. The same policy would save the institutions from the observed malpractices, underutilization and wastages of resources.

\section{References}

[1]. Amenyedzi, F.W.K., Lartey, M.N., \& Dzomeku, B.M. (2011). The Use of Computers and Internet as Supplementary Source of Educational Material: A case Study of the Senior High Schools in the Tema Metropolis in Ghana. Contemporary Educational Technology, 2011, 2 (2), 151-162. Retrieved from HYPERLINK "http://www.cedtech.net/articles/22/224.pdf" http://www.cedtech.net/articles/22/224.pdf , accessed on 17th February 2014

[2]. Auerswald, M. \& Magambo, J. (2006). Fostering ICT use in teacher education in Africa. Retrieved from http://www.unikoeln.de/philfak/afrikanistik/kant/data/AMI_kant1.pdf, accessed on 27th January 2010

[3]. Balasubramanian, K. (2009). ICTs for Higher Education, UNESCO-Commonwealth of Learning

[4]. Barney, J. (1991). Firm resources and sustainable competitive advantage, Journal of Management, 17(1), 99- 120.

[5]. Bashir, S., Mahmood, K. \& Shafique, F. (2008). Internet Use among University Students: A Survey in University of the Punjab, Lahore. Retrieved from HYPERLINK "http://pu.edu.pk/images/journal/pjlis/Previous\%20Issue/pjlis-9-mahmood.pdf" http://pu.edu.pk/images/journal/pjlis/Previous\%20Issue/pjlis-9-mahmood.pdf , accessed on 17th February 201

[6]. Blurton, C. (1999). New Directions of ICT-Use in Education, UNESCO

[7]. Bridoux, F. (1997). A Resource-Based Approach to Performance And Competition: An Overview of the Connections between Resources and Competition, Institut d'Administration et de Gestion, Université catholique de Louvain. Retrieved from $\square$ HYPERLINK "https://www.uclouvain.be/cps/ucl/doc/iag/documents/WP_110_Bridoux.pdf" https://www.uclouvain.be/cps/ucl/doc/iag/documents/WP_110_Bridoux.pdf , accessed on 25th February 2014

[8]. Capshaw, C. N. (2007). The quality of higher education, internet and computer technologies: exacerbating or lessening differences across countries?An analysis at three levels: national, institutional, and classroom. A Dissertation Submitted to the Faculty of the Graduate School of Vanderbilt University in partial fulfillment of the requirements for the degree of Doctor of Philosophy in Leadership and Policy Studies May, 2007 Nashville, Tennessee

[9]. Carnoy, M. (2004). ICT in Education : Possibilities and Challenges. Inaugural Lecture of the 2004-2005 Academic Year. Retrieved from http//www.uoc.edu/inaugural04/dt/eng/carnoy1004.pdf, accessed on 5th July 2009

[10]. Conner, K. (1991). A historical comparison of resource-based theory and five schools of thought within industrial organization economics: Do we have a new theory of the firm? Journal of Management, 17(1), 121-154.

[11]. Crest (2007). Rwandan Science and Technology System- A brief profile. Retrieved from HYPERLINK "http://www.research_africa_net/media/pdf/Rwandatelprofile.pdf" http://www.research_africa_net/media/pdf/Rwandatelprofile.pdf , accessed on 11th December 2009

[12]. Duderstadt, D. A. \& Houweling, V. D. (Eds.) (2002). Higher Education in the Digital Age: Technology Issues and Strategies for American Colleges and Universities. ACE/Praeger Series on Higher education, The Oryx Press.

[13]. Farrell, G. \& Shafika, I. (2007). Survey of ICT and Education in Africa: A Summary Report, Based on 53 Country Surveys. Washington, DC. InfoDev World Bank. Retrieved from HYPERLINK "http://www.infodev.org/en/Publication.353.html" http://www.infodev.org/en/Publication.353.html , accessed on 29th December 2010

[14]. Friedrich, H.F. \& Hron, A. (2011). Factors affecting teachers' student-centered classroom computer Use. Educational Media International, Vol. 48, No. 4, December 2011, 273-285, Retrieved from HYPERLINK "http://web.b.ebscohost.com/ehost/detail?vid=9\&sid=a35080ce-9fd1-4646-aaab-

7ac22d6e0b1d\%40sessionmgr198\&hid=122\&bdata=JnNpdGU9ZWhvc3QtbG12ZQ\%3d\%3d\#db=eric\&AN=EJ948171" http://web.b.ebscohost.com/ehost/detail?vid=9\&sid=a35080ce-9fd1-4646-aaab-

7ac22d6e0b1d\%40sessionmgr198\&hid=122\&bdata=JnNpdGU9ZWhvc3QtbGl2ZQ\%3d\%3d\#db=eric\&AN=EJ948171 , accessed on 16 th February 2014.

[15]. Government of Rwanda.(2001.An Integrated ICT-led socio-economic development policy and plan for Rwanda 2001-2005. Kigali, ECA-CEA.

[16]. Grant, R.M. (2001). The Resource-Based Theory of Competitive Advantage: Implications for Strategy Formulation. Retrieved from HYPERLINK "http://www.skynet.ie/ karen/Articles/Grant1_NB.pdf" http://www.skynet.ie/ karen/Articles/Grant1_NB.pdf , accessed on 25th February 2014

[17]. Haddad, W.D. \& Jurich, S. (2002). ICT for Education: Potential and Potency. Available online at http://www.iastate.edu (accessed 11 December 2009)

[18]. Hamel, G. \& Prahalad, C. (1996). Competing for the Future, Harvard Business School Press, Paperback edition, Boston (Massachusetts).

[19]. Hermes, A. (2012). eHow Contributor: The history of Computers in Schools. Retrieved from HYPERLINK "http://www.ehow.com/about 5491373 history-comters-schools.html" http://www.ehow.com/about 5491373 history-comtersschools.html , accessed on 10th February 2013.

[20]. Hayman, R.(2005).The contribution of the Post-Basic Education and Training (PBET) to poverty reduction in Rwanda : balancing short-term goals in the face of capacity constraints. Post-Basic education and training (Working Paper No.3) Edinburgh: University of Edinburgh.

[21]. Higgins, S. (2002). Does ICT Improve Learning and Teaching in Schools? A Professional User Review of UK research undertaken for the British Educational Research Association, New Castle University. Retrieved from http:www.bera.ac.uk/publications/pdfs/ICT, accessed on 10th February 2010

[22]. Kaahwa, J. (2013). Use of Computers in Uganda Schools. WynoJournal of Educational Research and Essays, Vol 1(2)pp. 9-17 March 2013, Makerere University, Kampala. Retrieved from , accessed on 17th February 2014

[23]. Kostopoulos, K.C., Spanos, Y.E. \& Prastacos, G.P. ( nd). The Resource -Based View of the Firm and Innovation: Identification of Critical Linkages. Retrieved from HYPERLINK "http://ecsocman.hse.ru/data/165/663/1219/rb_view.pdf" http://ecsocman.hse.ru/data/165/663/1219/rb_view.pdf , accessed on 25th February 2014

[24]. Ministry of Education, Republic of Rwanda-MINEDUC (2010). ICT in Education Policy. Draft Maldonado, H. (2001, p. 16).”Should Computers go to School? A Cost-Effectiveness Perspective." Stanford University School of Education (mimeo)

[25]. Ministry of Education, Republic of Rwanda -MINEDUC (2007). The Future of Higher Education in Rwanda: A Policy Framework, Draft copy, Kigali, May 2007

[26]. Ministry of Youth and ICT, Republic of Rwanda (2012). Rwanda ICT Sector Profile - 2012:"Measuring ICT sector performance and Tracking ICT for Development (ICT4D) towards Rwanda Socio-Economic Transformation". Retrieved from $\square$ HYPERLINK "http://admin.theiguides.org/Media/Documents/Rwanda-ICT-Profile-2012.pdf" 
http://admin.theiguides.org/Media/Documents/Rwanda-ICT-Profile-2012.pdf , accessed on17th February 2014. NIMECOFIN.(2004).Rwanda development indicators; 7th Edition. Republic of Rwanda, NIMECO-FIN, Department of Statistics. NIMEDUC.(1998).Study of Education sector in Rwanda. Kigali Ministry of Education.

Mukama.E (2012). Education in urban areas in Rwanda. Urbanization and Education in East Africa. African Population and Health Research Centre. Nairobi, Kenya.

[27]. Mukama, E. \& Andersson, S.B. (2008). Coping with change in ICT-based learning environments: newly qualified Rwandan teachers' reflections. Journal of Computer Assisted Learning (2008), 24, 156-166. Retrieved from HYPERLINK "http://www.gesci.org/assets/files/Article1-Coping\%20with\%20change.pdf" http://www.gesci.org/assets/files/Article1Coping\%20with\%20change.pdf , accessed on 16th February 2014

[28]. Murenzi, R. (2008). Towards an ICT Hub for Long Term Economic Growth, A presentation in Serena Hotel Kigali, Thursday October 30th, 2008

[29]. Nsengiyumva, A. \& Stork, C. (2005). Towards an African e-Index: ICT Access andUsage. Retrieved from HYPERLINK "http://links.wits.c.za" http://links.wits.c.za , accessed on 11th August2009

Osorio, F.B. \& Linden, L.L. (2009). The Use and Misuse of Computers in Education: Evidence from a Randomized Experiment in Colombia, Impact Evaluation Series No. 29, The world Bank, Retrieved from HYPERLINK "http://siteresources.worldbank.org/EDUCATION/Resources/278200-1099079877269/547664-1099079934475/547667-

1145313958806/WPS4836_Computers_Edu_Colombia.pdf" http://siteresources.worldbank.org/EDUCATION/Resources/2782001099079877269/547664-1099079934475/547667-1145313958806/WPS4836_Computers_Edu_Colombia.pdf , accessed on 20th February 2014

[30]. Pedro, F. (2004). Comparing Traditional and ICT-Enriched University Teaching Methods: Evidence from two Empirical Studies. Paris: UNESCO. Retrieved from http//www.oecd.org, accessed on 12th July 2009 Pelgrum, W.J. \& Law. N. (2003). ICT in Education around the world: Trends, Problems and Prospects. Paris: UNESCO.

[31]. Roekel, D.V. (2008). Technology in Schools: The Ongoing Challenge of Access, Adequacy and Equity. An NEA policy brief, Washington, D.C. Retrieved from HYPERLINK "http://www.nea.org/assets/docs/PB19_Technology08.pdf" http://www.nea.org/assets/docs/PB19_Technology08.pdf , accessed on 18th February 2014

[32]. Sahin, Y.G., Balta, S. \& Ercan, T. (2010). The use of Internet Resources by university students during their course projects elicitation: A case study. The Turkish Online Journal of Educational Technology-April 2010, Volume 9, Issue 2. Retrieved from HYPERLINK "http://www.tojet.net/articles/v9i2/9224.pdf" http://www.tojet.net/articles/v9i2/9224.pdf , accessed on 18th February 2014

[33]. Sang, G., Valcke, M., Braak, J.V., Tondeur, J. \& Zhu, C. (2010). Predicting ICT integration into classroom teaching in Chinese primary schools: exploring the complex interplay of teacher-related variables. Journal of Computer Assisted Learning (2011), 27, 160172. Retrieved from HYPERLINK "http://web.b.ebscohost.com/ehost/pdfviewer/pdfviewer?vid=9\&sid=a35080ce-9fd1-4646-aaab7ac22d6e0b1d\%40sessionmgr198\&hid=122" http://web.b.ebscohost.com/ehost/pdfviewer/pdfviewer?vid=9\&sid=a35080ce-9fd14646-aaab-7ac22d6e0b1d\%40sessionmgr198\&hid=122, accessed on 16th February 2014

[34]. Selwyn, N. (2006). The use of computer technology in university teaching and learning: a critical perspective. Journal of Computer

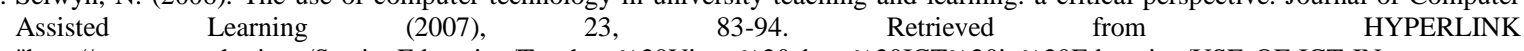

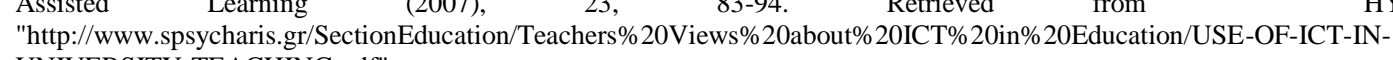
UNIVERSITY-TEACHING.pdf"

http://www.spsycharis.gr/SectionEducation/Teachers\%20Views\%20about\%20ICT\%20in\%20Education/USE-OF-ICT-INUNIVERSITY-TEACHING.pdf , accessed on 18th February 2014

Ssempebwa, J., Canene, A.P \& Mugabe, M. (2007). ICT investment in Rwandan Higher Education: Highlighting the Cost of Downtime and End-Users'Operations. Research Digest, Vol 1, No 1, November 2007, Kampala International University

[35]. Venezky, R. \& Cassandra, D. (2002). "Quo Vademus? The Transformation of Schooling in a Networked World.” Paris: OECD/CERI, Version 8c, March 6

[36]. Zhou, L., Shirley, N.G., Kelley, P., Banda, D.R., Lan, W.Y., Parker, A.T. \& Smith, D.W. (2012). The Relationship between Computer and Internet Use and Performance on Standardized Tests by Secondary School Students with Visual Impairments. Journal of Visual Impairment \& Blindness, October-November 2012, Retrieved from HYPERLINK "http://web.b.ebscohost.com/ehost/pdfviewer/pdfviewer?vid=13\&sid=a35080ce-9fd1-4646-aaab-

7ac22d6e0b1d\%40sessionmgr198\&hid=122" http://web.b.ebscohost.com/ehost/pdfviewer/pdfviewer?vid=13\&sid=a35080ce-9fd14646-aaab-7ac22d6e0b1d\%40sessionmgr198\&hid=122 , accessed on 15th February 2014

[37]. Ziphorah, R.M.(2011). The Provision of Basic Levels of Computer Literacy and Education to the Neediest Community in South Africa, International Journal for e-Learning Security (IJeLS), Volume 1, Issues 3/4, September/December 2011. Retrieved from HYPERLINK "http://www.infonomicssociety.org/IJeLS/The $\% 20$ Provision $\% 20$ of $\% 20$ Basic\%20Levels $\% 20$ of $\% 20$ Computer\%20Literacy\%20and $\% 20$ Education $\% 20$ to $\% 20$ th e $\% 20$ Neediest $\% 20$ Community\%20in\%20South\%20Africa.pdf" http://www.infonomicssociety.org/IJeLS/The\%20Provision\%20of\%20Basic\%20Levels\%20of\%20Computer\%20Literacy\%20and\%20Education\%20to\%20th e\%20Neediest\%20Community\%20in\%20South\%20Africa.pdf , accessed on 19th February 2014. 